\title{
Oxidative Stress, Physiological Responses and Performance of Broilers Transported with Different Transportation Duration
}

Stres Oksidatif, Respon Fisiologi, dan Perfoma Broiler yang Ditransportasikan dengan Durasi yang Berbeda

M. A. Wicaksono ${ }^{1 *}$, R. Afnan ${ }^{2}$, \& T. Suryati ${ }^{2}$

${ }^{1}$ Graduate School of Animal Production Science and Technology, Faculty of Animal Science, IPB University

${ }^{2}$ Department of Animal Production and Technology, Faculty of Animal Science, IPB University

Agatis St, IPB Dramaga, Bogor 16680, Indonesia

*Corresponding author: abiwcksn27@gmail.com

(Received 07-07-2020; Revised 03-08-2020; Accepted 27-08-2020)

\begin{abstract}
Transportation plays important factor in broiler industry. Whole transportation process from loading to unloading can cause stress to broilers. The duration of the trip can affect oxidative stress, physiological and performance of broiler. This study aim to evaluate the effects of different transportation durations on oxidative stress, physiological responses and performance of broilers. Transportation from farm to slaughterhouse using a truck with a capacity of 144 crates. There were two durations treatment in this study, 180 and 240 mins. Variables measured in this study were oxidative stress indicators (malondialdehyde/ MDA content and catalase enzyme activity), physiological responses (rectal temperature and heterophile lymphocytes (HL) ratio), and performance represented by weight loss percentage. Normality test was done before $T$ Test. Data analyzed using $T$ Test independent which compared data between before and after transportation. $T$ Test dependent which compared data between short and long duration. The result showed that duration of transportation significantly affects on decrease liver and thigh catalase enzyme activity, decrease malondialdehyde value on liver, decrease HL ratio after transportation, differences on rectal temperature and weightloss. Long transportation duration resulted the lowest liver and thigh catalase enzymes activity $(0.097 \pm 0.023$ and $0.088 \pm 0.014 \mathrm{U} / \mathrm{mL})$. It can be concluded that the long duration transportation catalase enzyme activity reduce MDA value and affected performance indicator.
\end{abstract}

Keywords: broiler, oxidative stress, physiology response, transportation

\section{ABSTRAK}

Transportasi merupakan faktor penting pada industri broiler. Proses transportasi mulai dari loading sampai unloading merupakan titik kritis. Durasi perjalanan dapat memengaruhi stres oksidatif, respon fisiologis, dan performa. Penelitian ini bertujuan untuk mengevaluasi efek dari durasi transportasi yang berbeda terhadap stres oksidatif, respon fisiologis, dan performans. Transportasi dari kandang menuju Rumah Potong Ayam menggunakan truk dengan kapasitas 144 keranjang. Dua perlakuan pada penelitian ini, yaitu durasi 180 dan 240 menit. Peubah yang diamati pada penelitian ini adalah stres oksidatif (malondialdehide dan aktivitas enzim katalase), respon fisiologis (suhu rektal dan Rasio heterofil limfosit), dan persentase susut bobot. Uji normalitas dilakukan sebelum Uji T. Uji T independen membandingkan antar perlakuan dan Uji $T$ dependen membandingkan sebelum dan sesudah transportasi pada masing-masing perlakuan. Durasi transportasi memengaruhi penurunan aktivtias enzim katalase hati dan daging bagian paha, penurunan nilai malondialdehide hati, penurunan rasio HL sesudah transportasi, dan selisih peningkatan suhu rektal dan penyusutan bobot badan. Durasi yang panjang menunjukkan nilai terkecil pada aktivitas enzim katalase $(0.097 \pm 0.023$ dan $0.088 \pm 0.014 \mathrm{U} / \mathrm{mL})$. Dapat disimpulkan bahwa durasi transportasi yang lebih lama aktivitas katalase bekerja menurunkan nilai MDA dan memengaruhi performa broiler.

Kata kunci: broiler, respon fisiologis, stres oksidatif, transportasi 


\section{INTRODUCTION}

Transportation plays important role in the broiler industry. Commercial broilers are often transported without proper handling and respect to welfare that cause potential losses such as weight loss and event death. Three main factors to be considered in carrying out transportation are conditions of broilers, vehicles, and human resources. Broiler and vehicle conditions must be fit for transport process to prevent losses during transport process. Human resources must have appropriate competence for transportation process starting from loading, travelling, and unloading.

Transport duration can affect the condition of broiler. Traffic situation in Indonesia is relatively difficult to handle, traffic jams can occur unpredictedtably especially in West Java which had many broiler industries. Unevent road surface can cause lot of shocks to broiler during transport. Broilers transportation in Indonesia uses various types ranging from trucks with a capacity of 144 crates or a pickup truck with a smaller crate capacity. Therefore, in Indonesia travel distance is not suitable and rarely used to measure its effect on broilers. Death risk in travel can be caused by health status of broilers as they are sensitive to environmental conditions (Bayliss and Hinton 1990, Mitchell and Kettlewell 2009). Heat load during transport process occur at loading, travelling, and conditions in the crates, and unloading (Whiting et al. 2007).

Crate density can affect the microclimate in a vehicle. Optimal relative humidity for broilers ranges from $60 \%$ to $70 \%$. Temperature above $28{ }^{\circ} \mathrm{C}$ and humidity up to $80 \%$ cause an increase body temperature to $0.42{ }^{\circ} \mathrm{C}$ per hour (Mitchell and Kettlewell 1994). Broiler physiology response during transportation can describe the level of stress experienced. Some physiological responses that are usually measured as stress indicators are blood profile, oxidative stress, and catalase enzyme activity in liver and meat.

Blood profile can describe the stress level of broiler. Broiler transportation with a distance of $120 \mathrm{~km}$ reduces levels of hemoglobin, hematocrit, and blood triglycerides (Purwadi 2008). Stress can be observed from the number of leukocytes and heterophyl lymphocytes ratio. The increased numbers of leukocytes beyond the normal limit can indicate the presence of stress in broiler. Heterophyls and lymphocytes are parts of leukocytes.

This research aimed to evaluate the microclimate, physiological reponse, blood profiles, oxidative stress, and weight loss in broilers during transportation with different duration. The results obtained are expected to provide input to the broiler industry for optimizing the transportation duration process.

\section{MATERIALS AND METHODS}

\section{Materials}

Transportation from farm to slaughterhouse using a truck with a capacity of 144 crates. On one crates there were 14 to 15 broilers. On one vehicle can transport 20162160 broilers. to In one treatment three replications were carried out on the same vehicle.

\section{Treatment}

The treatment was the length of trip from farm to the chicken slaughterhouse. Following the company operational procedure. Farm and slaughterhouse is located at Parung, Bogor. There were two duration treatments, P180 and P240 which were 180 and 240 minutes. Initial time of transport from farm to slaughter house was at $01.30 \mathrm{WIB}$ and at 00.00 WIB respectively.

\section{Measurement of Variables}

Temperature and humidity during transport process were recorded. Body weight, rectal temperature, and blood sampling was taken and measured before and after the transportation process from the same individual animals. In one treatments used six individual animals for blood, body weight, and liver and thigh sampling. Body weight depreciation seen from difference body weight before and after transportation. Oxidative stress was examined from liver and lower thigh meat using Singh methods for malondialdehyde analysis and Iwai methods for catalase analysis.

\section{Temperature Humidity Index (THI)}

Temperature humidity index (THI) was determined from wet and dry temperature of environment. Digital data logger was installed at $50 \mathrm{~cm}$ from the surface of the vehicle to measure temperature and humidity of the environment. Data logger measure temperature and humidity during transportation process. THI calculation used the formula of $(0.85 \mathrm{x}$ dry temperature $)+(0.15 \mathrm{x}$ wet temperature $)$ (Tao and Xin 2003).

\section{Rectal Temperature}

Rectal broiler temperature was measured using APPA digital thermometer. This thermometer was inserted 2-3 cm depth into broiler rectal. Measurement was stopped when the temperature was fix.

\section{Heterophile Lymphocyte Ratio}

Heterophile lymphocyte ratio was tested using metode of Bain (2005). The ratio of heterophile lymphocytes ration was determined by comparing the percentage of heterophils and lymphocytes. Leucocyte differentiation was run to get the number of heterophile and lymphocyte.

Leucocyte differentiation was applied by observing the shape of blood body and calculate its percentage, afterwards. Blood sample preparations followed the common procedure by using Giemsa's solution. The preparate was fixed with methanol solution for five minutes. A microscope used to observe the the shape of blood body and percentage was then calculated.

\section{Malondialdehyde Analysis}

Malondialdehyde (MDA) was tested using method of Singh (2002). Liver and meat of $1.25 \mathrm{~g}$ each was chopped until smooth then mixed with $5 \mathrm{~mL}$ of PBS solution under cold conditions $\left(0{ }^{\circ} \mathrm{C}\right.$ to $\left.4{ }^{\circ} \mathrm{C}\right)$. Homogenates were centrifuged at $4500 \mathrm{rpm}$ for 10 minutes to get supernatant. Extracts with concentrations of 25,50 , and $100 \mathrm{ppm}$ 
(dissolved in $\mathrm{EtOH}$ ) were put into a test tube and allowed to evaporate until dry. One $\mathrm{mL}$ potassium chloride 0.2 $\mathrm{mM}$ and $0.5 \mathrm{~mL}$ homogenate were inserted into test tube. Peroxidation formed by adding $100 \mu \mathrm{L}$ ferric chloride 0.2 $\mathrm{mM}$. Incubation at $37{ }^{\circ} \mathrm{C}$ for 180 minutes was performed by adding $2 \mathrm{~mL}$ of cold $0.25 \mathrm{~N} \mathrm{HCl}$ (15\% trichloroacetic acid (TCA), $0.38 \%$ TBA, and $0.5 \%$ BHT). The solution was heated at $80{ }^{\circ} \mathrm{C}$ for 60 minutes. The sample was cooled at room temperature and then centrifuged and measured on a spectrophotometer with absorbance of $532 \mathrm{~nm}$.

\section{Catalase Activity}

Catalase enzyme activity was tested using Iwai method (2002). Liver and broiler meat of $1.25 \mathrm{~g}$ each was chopped until smooth and then PBS solution was added with a $\mathrm{KCl}$ content of $1.15 \%$ and centrifuged at $10000 \mathrm{rpm}$ for 10 minutes. A supernatant of $0.125 \mathrm{~mL}$ was added with $0.5 \mathrm{~mL}$ of potassium phosphate buffer $(\mathrm{pH} 750 \mathrm{mM})$ containing 10 $\mathrm{mM}$ of hydrogen peroxide in a quartz cuvette. Absorbance measured at $240 \mathrm{~nm}$ was recorded every 15 seconds for 1 minute using a spectrophotometer. Catalase activity $(\mathrm{U} / \mathrm{mL})$ was calculated as follows: (sample-blank / 0.0436) (2.5/ $0.5)$.

\section{Data Analysis}

Normality test was done before T Test. Data analyzed using $\mathrm{T}$ Test independent which compared data between before and after transportation for rectal temperature, heterophyl, lymphocytes, HL ratio, and body weight. T Test dependent which compared data between short and long duration for temperature humidity index, temp difference, HL ratio difference, malondialdehyde value, and catalase enzyme actitviy.

\section{RESULTS AND DISCUSSION}

\section{Temperature Humidity Index (THI)}

Temperature, humidity, and THI were significantly different between treatments both outside and inside crates. THI outside crates at P240 treatment was higher than P180 (Table 2), whereas THI inside crates at P180 was higher than P240 (Table 1). THI outside crates was more influenced by temperature of environment, while THI inside crates was influenced by temperature of environment as well as heat generated by broilers inside crates.
Transportation P180 was started at 01.30 WIB from farm and arrived at slaughterhouse at 03.45 WIB (150 minutes), while P240 was started at 23.50 WIB from farm and arrived at slaughterhouse at 04.15 WIB (265 minutes). The difference in departure time (between P180 and P240) for two hours resulted differently ambient temperature. The difference in travel time P180 (150 minutes) and P240 (265 minutes) also had supported by differences in air humidity. The trip in early morning, more affected by higher humidity and affects THI outside crates. This results in a decrease in wet temperature Twb which was higher at P240 because much heat was absorbed by water. Although transported in early hours morning, THI values in two treatments showed tense environmental conditions for broilers. According to results from Scanes (2004) that broilers were in a comfort zone with an ambient temperature of 18 to $24^{\circ} \mathrm{C}$ with a humidity of 50 to $75 \%$.

According to Mitchell and Kettlewell (2009), dry temperature inside crates must be maintained in range of 23 to $24^{\circ} \mathrm{C}$ therefore broiler was in comfort zone. In this study showed that the dry temperatures ranged from 28 to $28.9^{\circ}$ $\mathrm{C}$, and broilers should be in a stress condition.

Temperature and humidity were climatic factors that interrelated. Higher temperatures cause increased respiratory activity and result in increased humidity in crates. The humidity in crates was increased followed with broilers heat production resulted in broilers being in a wet condition which affects the weight measurement after transportation. This is in line with the statement of Joseph et al. (2012) that $\mathrm{THI}$ values exceeding $21^{\circ} \mathrm{C}$ cause an increased in broiler body temperature by $1.7^{\circ} \mathrm{C}$ that indicate increased body heat production. Increased broiler body temperature is one of characteristics broiler feel stress. Excessive heat production will increase the dry temperature in crates.

\section{Rectal Temperature}

The temp difference was not significantly different it means the transportation process has not caused stress in rectal temperature response (Table 3 ). The optimal rectal temperature for broilers in hot climate is at 40.5 to 41.5 (Etches et al. 2008). Panting is caused by environmental conditions from high temperatures and humidity. Panting is indicating broilers experiencing stress and affects body heat production it can be seen in rectal temperature. In

Table 1. Temperature Humidity Index inside crates at short and long duration

\begin{tabular}{lcccc}
\hline Treatments & Temperature dry bulb $\left({ }^{\circ} \mathrm{C}\right)$ & $\mathrm{Rh}(\%)$ & Temperature wet bulb $\left({ }^{\circ} \mathrm{C}\right)$ & THI \\
\hline P180 & $28.90 \pm 0.56 \mathrm{a}$ & $85.15 \pm 2.42 \mathrm{a}$ & $26.04 \pm 0.57 \mathrm{~b}$ & $27.78 \pm 0.54 \mathrm{a}$ \\
P240 & $28.00 \pm 0.07 \mathrm{~b}$ & $76.08 \pm 0.7 \mathrm{~b}$ & $24.64 \pm 0.17 \mathrm{a}$ & $27.49 \pm 0.09 \mathrm{~b}$ \\
\hline
\end{tabular}

Note: "Means in the same column with different superscript differ significantly $(\mathrm{P}<0,05)$ ". Note: P180=Treatment with duration 180 minutes; P240=Treatment with duration 240 minutes.

Table 2. Temperature Humidity Index outside crates at short and long duration

\begin{tabular}{lcccc}
\hline Treatments & Temperature dry bulb $\left({ }^{\circ} \mathrm{C}\right)$ & $\mathrm{Rh}(\%)$ & Temperature wet bulb $\left({ }^{\circ} \mathrm{C}\right)$ & THI \\
\hline P180 & $26.40 \pm 0.88 \mathrm{~b}$ & $96.10 \pm 3.29 \mathrm{a}$ & $25.95 \pm 0.67 \mathrm{a}$ & $26.25 \pm 0.75 \mathrm{~b}$ \\
P240 & $27.89 \pm 0.08 \mathrm{a}$ & $75.64 \pm 0.55 \mathrm{~b}$ & $24.47 \pm 0.15 \mathrm{~b}$ & $27.38 \pm 0.09 \mathrm{a}$ \\
\hline
\end{tabular}

Note: "Means in the same column with different superscript differ significantly $(\mathrm{P}<0,05)$ ". Note: $\mathrm{P} 180=$ Treatment with duration 180 minutes; P240=Treatment with duration 240 minutes. 
Table 3. Broiler rectal temperature before and after transportation

\begin{tabular}{|c|c|c|c|}
\hline \multirow[t]{2}{*}{ Treatments } & \multicolumn{2}{|c|}{ Rectal temperature } & \multirow{2}{*}{$\begin{array}{c}\text { Temp } \\
\text { difference }\end{array}$} \\
\hline & $\begin{array}{c}\text { Before } \\
\text { transportation }\end{array}$ & $\begin{array}{c}\text { After } \\
\text { transportation }\end{array}$ & \\
\hline P180 & $41.517 \pm 0.293 b$ & $41.730 \pm 0.308 b$ & $0.217 \pm 0.214 \mathrm{~ns}$ \\
\hline P240 & $41.817 \pm 0.475 \mathrm{a}$ & $41.917 \pm 0.462 \mathrm{a}$ & $0.100 \pm 0.120 \mathrm{~ns}$ \\
\hline
\end{tabular}

Note: "Means in the same column (a and b) with different superscript differ significantly $(\mathrm{P}<0,05)$ )". P180=Treatment with duration 180 minutes; P240=Treatment with duration 240 minutes.

this study there was no broilers from total (12 broilers) had panting. THI inside crates that exceeds $21^{\circ} \mathrm{C}$ affect to broiler temperature increased up to $1.7^{\circ} \mathrm{C}$ above normal body temperature $\left(41^{\circ} \mathrm{C}\right)$ (Joseph et al. 2012). In this study THI inside crates exceeds $21{ }^{\circ} \mathrm{C}$ so rectal temperature after transportation must be above normal body temperature.

The highest rectal temperature changes were obtained in P180 with broiler weights 1.6 to $1.8 \mathrm{~kg}$ with THI outside the crates of 26.25. The highest THI for outside crates (P240) not affect to rectal temperature differences. P180 rectal temperature differences was high than P240 because temperature was increased so affect to broiler metabolism.

\section{Heterophile, Lymphocyte and HL Ratio}

Table 4 showed that heterophile, lymphocyte, and HL ratio in the treatment of transport duration of 180 minutes (P180) and 240 minutes (P240) were significantly different between before and after transport. Heterophile values in P180 and P240 after transportation (32.5 and 30.17) decreased compares to before transportation (33.5 and 30.83). Decreased heterophile values illustrate that broilers did not experience stress. The heterophile values between treatments were significantly different. The heterophile value P240 (30.83 and 30.17) was smaller than P180 (33.5 and 32.5).

There was a difference in lymphocyte value after transportation for two treatments. There was an increase in P180 (58.33 to 58.83). Meanwhile a decrease was found in P240 (59.83 to 59.67). The lymphocyte between treatments differed significantly only before transportation, whereas P240 (59.83) has a higher value than P180 (58.33). The decrease of lymphocyte in P240 can be caused by a reduction in the weight of lymphoid organs including the Fabricius bursa due to heat stress (Siegel 1995). Broiler chickens will increase the secretion of glucocorticoid hormones and affect a decrease in the level of lymphocyte in the blood (Siegel 1995). High ambient temperature and humidity above normal can reduce the weight of Fabricius (Kusnadi 2009).
Heterophile has the function of a defense system against infection by a mechanism acting on the area infected by unidentified object. Meanwhile lymphocyte has the function of the formation of antibodies that have circulation in the blood and development of cellular immune systems (Frandson 1992). The heterophile value of broilers is highly influenced by animal genetic, livestock stress level during its life, environmental conditions both in the maintenance and overall transportation process, and adequacy in feed nutrients (Thaxton and Puvadolpirod 2000).

After transportation, the HL ratio of P180 and P240 decreased from 0.58 and 0.55 to 0.55 and 0.51 , accordingly. The HL ratio between treatments differed significantly. HL ratio of $\mathrm{P} 240$ (0.52 and 0.51$)$ was lower than of $\mathrm{P} 180$ ( 0.58 and 0.55$)$. The blood components determine the HL ratio as a stress indicator. HL ratio for broiler chickens and its classification in tropical climates were 0.2 (low), 0.5 (normal), and 0.8 (high) (Ernadi and Kermanshahi 2007). Both treatments did not cause stress to broiler chickens because the HL ratio was in the normal range. The change in the HL ratio between treatments was small and not significantly different. THI above 21 (both inside and outside crates) in this study is not followed by an increase in HL ratio. The blood sampling was taken one hour after arriving at the slaughterhouse following procedures set by the company. According to results from Hartati (2012) that the muscle glycogen recovered at the one hour rest period prior to slaughter. This recovery affects leukocyte value.

\section{MDA Content and Catalase Enzyme Activity}

Table 5 showed that the value of MDA oxidative stress was not significantly different. MDA value in the thighs in all treatments was relatively smaller than in liver, because in liver more oxidative processes occured (Guyton 1992). The highest THI outside crates (P240) is the lowest MDA value both in liver and thight. Transportation with longer duration decrease MDA value because catalase enzyme activity decreasing MDA value. One indicator of broilers experiencing oxidative stress is occurrence of lipid peroxidation which results in MDA (Aksu et al. 2010). Lipid oxidation will affect the quality of meat and even cause damage so it cannot be consumed (Jiang et al. 2007). Free radicals in broiler will interfere several systems such as growth, reproduction, and endurance (Gladine et al. 2007).

MDA value of 0.053 to 0.389 in this study showed that broiler meat was still suitable for consumption. Observation and analysis during oxidative stress analysis showed that carcass and internal organs were still in normal condition and no physical changes occurred. The condition of carcasses and internal organs that were fresh or fit for

Table 4. Heterophile, lymphocyte, and HL ratio broilers before and after transportation at short and long duration

\begin{tabular}{lccccccc}
\hline Treatments & \multicolumn{2}{c}{ Heterophile (\%) } & \multicolumn{2}{c}{ Lymphocyte $(\%)$} & \multicolumn{2}{c}{ HL Ratio } & \multirow{2}{*}{$\Delta$ HL Ratio } \\
\cline { 2 - 7 } & $\begin{array}{c}\text { Before } \\
\text { transpotation }\end{array}$ & $\begin{array}{c}\text { After } \\
\text { transportation }\end{array}$ & $\begin{array}{c}\text { Before } \\
\text { transportation }\end{array}$ & $\begin{array}{c}\text { After } \\
\text { transportation }\end{array}$ & $\begin{array}{c}\text { Before } \\
\text { transportation }\end{array}$ & $\begin{array}{c}\text { After } \\
\text { transportation }\end{array}$ & \\
\hline P180 & $33.50 \pm 1.38 \mathrm{ax}$ & $32.50 \pm 1.52 \mathrm{ay}$ & $58.33 \pm 1.63 \mathrm{by}$ & $58.83 \pm 1.60 \mathrm{x}$ & $0.58 \pm 0.04 \mathrm{ax}$ & $0.55 \pm 0.04 \mathrm{ay}$ & $0.043 \pm 0.031 \mathrm{~ns}$ \\
$\mathrm{P} 240$ & $30.83 \pm 0.75 \mathrm{bx}$ & $30.17 \pm 0.98 \mathrm{by}$ & $59.83 \pm 1.47 \mathrm{ax}$ & $59.67 \pm 1.03 \mathrm{y}$ & $0.52 \pm 0.02 \mathrm{bx}$ & $0.51 \pm 0.01 \mathrm{by}$ & $0.019 \pm 0.018 \mathrm{~ns}$ \\
\hline
\end{tabular}

Note: "Means in the same column (a and b) and row ( $\mathrm{x}$ and $\mathrm{y})$ with different superscript differ significantly $(\mathrm{P}<0,05)$ ". $\mathrm{P} 180=$ Treatment with duration 180 minutes; P240=Treatment medium duration 240 minutes. 
Table 5. Malondialdehdyde value in liver and thigh at short and long duration

\begin{tabular}{lcc}
\hline Treatment & MDA liver $(\mathrm{mg} / \mathrm{kg})$ & MDA thigh $(\mathrm{mg} / \mathrm{kg})$ \\
\hline P180 & $0.636 \pm 0.827 \mathrm{~ns}$ & $0.389 \pm 0.117 \mathrm{~ns}$ \\
P240 & $0.252 \pm 0.698 \mathrm{~ns}$ & $0.053 \pm 0.183 \mathrm{~ns}$ \\
\hline
\end{tabular}

Note:"Means in the same column with different superscript differ significantly $(\mathrm{P}<0,05)$ ". $\mathrm{P} 180=$ Treatment with duration 180 minutes; $\mathrm{P} 240=$ Treatment with duration 240 minutes

consumption was it can be seen by no change in color or texture, has a reddish white color, texture is not too wet, and does not have a pungent aroma.

Broilers have capability to adapt stress as indicated by MDA impairment. The normal value of MDA broiler is 0.5 . MDA value of meat has a smaller value than the MDA organ (Guyton 1992). The internal organs work more against oxidative stress because organs such as the liver carry out the cleansing process of the body. The mechanism of oxidative stress in broiler due to stress is the formation of reactive oxygen species that have no bonds.

The catalase activity in this study showed significantly different results in both liver and thighs. Catalase enzymes in broilers were antioxidant enzymes that work to reduce high oxidative stress values. The catalase enzyme pattern obtained in this study also has a smaller tendency in longer duration of the trip (Table 6). The lowest THI inside crates (P240 27.49) affected catalase enzyme activity both in liver and thight were lower than other treatments $(0.097$ and 0.088). The longer the duration of transportation journey, the smaller MDA value produced, less catalase enzyme that works. The longer duration (P240) had lower catalase enzyme activity means catalase enzyme works to decrease MDA value.

Catalase enzyme activity in blood and tissue is a sign of metabolic abnormalities. Catalase enzyme is main enzyme because it work by giving hydrogen atoms to radical compounds, then radical compounds will become more stable. Catalase enzyme activity can function optimally supported by availability of other antioxidants in broiler system. Oxidation of fatty acids in broilers also starts from liver and therefore liver will be easily attacked by free radicals which were result of fat metabolism reactions (Guyton 1992). Tables 5 and 6 show the oxidation value that occurs in liver was higher than thigh.

Catalase enzyme function to reduce MDA value depending on availability of antioxidants in system (Aluwong 2015). Catalase enzym activity decrease if there is an increase production of MDA, when MDA cross linking with protein in amino acid grpup which will
Table 6. Catalase enzyme activity in liver and thigh at short and long duration

\begin{tabular}{lcc}
\hline Treatment & $\begin{array}{c}\text { Liver catalase } \\
(\mathrm{U} / \mathrm{mL})\end{array}$ & $\begin{array}{c}\text { Thigh catalase } \\
(\mathrm{U} / \mathrm{mL})\end{array}$ \\
\hline $\mathrm{P} 180$ & $0.148 \pm 0.073 \mathrm{a}$ & $0.165 \pm 0.084 \mathrm{a}$ \\
$\mathrm{P} 240$ & $0.097 \pm 0.023 \mathrm{~b}$ & $0.088 \pm 0.014 \mathrm{~b}$ \\
\hline
\end{tabular}

Note: "Means in the same column with different superscript differ significantly $(\mathrm{P}<0,05)$ ". $\mathrm{P} 180=$ Treatment with duration 180 minutes; P240=Treatment with duration 240 minutes

form cross molecules thus inactivating membrane enzyme bonds (Bhogade et al. 2008). In general, catalase serves to reduce cell damage caused by free radicals. The catalase enzyme functions to reduce level of free radicals in body by breaking down hydrogen peroxide into oxygen and water so that it is easily broken down. Degradation of free radical compounds occurs so that there is no damage to macro molecular components of cells (Valko et al. 2007).

In addition to enzyme catalase that works to reduce levels of free radicals, broiler also has superoxide dismutase and glutathione peroxidase enzyme. Some cases in the field, breeders provide additional enzymes both natural and synthetic, one of which is herbal ingredients (David et al. 2012).

The lower MDA value produced, catalase enzyme activity also decreases. This was found in the analysis of both liver and thighs. This happens because there is catalase enzym activity which gives hydrogen atoms to free radical compounds so that it becomes more stable.

\section{Weight Loss Percentage}

Weight loss percentage showed that the results were not significantly different (Table 7). Reduction in body weight ranges from 0.055 to 0.085 . Observation of broiler behavior of entire sample observed resulted no individuals experiencing stress. The highest weight loss results obtained in P240 (5.266 \%) there the highest THI outside crates (27.38) . P240 transportation duration was longer than P180 so affect to broiler weight loss caused by several factors such as genetic broilers, broiler health status, road conditions during trip, and THI.

\section{CONCLUSION}

The longer transportation duration affects oxidative stress there was decrease catalase enzyme activity and affects perfomance responses there was increase weightloss. HL ratio differences, rectal temperature differences, and MDA values not affected by transportation duration.

Table 7. Broiler weight loss at short and long duration

\begin{tabular}{lcccc}
\hline Treatments & \multicolumn{2}{c}{ Weight $(\mathrm{kg} / \mathrm{head})$} & \multicolumn{2}{c}{ Weight loss } \\
\cline { 2 - 5 } & Before & After & Kilogram & $\%$ \\
\hline P180 & $1.592 \pm 0.152 \mathrm{x}$ & $1.537 \pm 0.146 \mathrm{y}$ & $0.055 \pm 0.017 \mathrm{~b}$ & $3.421 \pm 0.991 \mathrm{~b}$ \\
P240 & $1.605 \pm 0.105 \mathrm{x}$ & $1.520 \pm 0.104 \mathrm{y}$ & $0.085 \pm 0.038 \mathrm{a}$ & $5.266 \pm 2.342 \mathrm{a}$ \\
\hline
\end{tabular}

Note: "Means in the same column (a and b) and row ( $\mathrm{x}$ and y) with different superscript differ significantly $(\mathrm{P}<0,05)$ ". $\mathrm{P} 180=$ Treatment with duration 180 minutes; P240=Treatment with duration 240 minutes. 


\section{ACKNOWLEDGEMENT}

The authors would like to acknowledge PT Sierad Produce for providing broiler transportation in this study.

\section{REFERENCES}

Aksu D. S., T. Aksu, B. Ozsoy, \& E. Baytok. 2010. The effects of replacing inorganic with a lower level of organically complexed minerals $(\mathrm{Cu}, \mathrm{Zn}$ and $\mathrm{Mn}$ ) in broiler diets on lipid peroxidation and antioxidant defense systems. Asian-Aust. J. Anim. Sci. 23:10661072.

Austic R. E. 2000. Feeding poultry in hot and cold climates, In: Yousef MK, editor, Stress physiology livest poultry Vol III (CRC Press Inc, Florida (US). 123-136.

Bain B. J. \& F. R. C. Path. 2005. Diagnosis from the Blood Smear. N. Engl. J. Med. 353: 498-507.

Bayliss P. A. \& M. H. Hinton. 1990. Transportation of Broilers with Special Reference to Mortality-Rates. Appl. Anim. Behav. Sci. 28. 93-118.

Bhogade R. B., A. N. Suryakar, N. G. Joshi, \& R. Y. Patil. 2008. Effect of vitamin E supplementation on oxidative stress in hemodialysis patients. Indian Journal of Clinical Biochemistry. 23 (3): 33-37.

David L. S., K. Vidanarachchi, H. W. Samarasinghe, Cyriland, \& C. M. B. Dematawewa. 2012. Effects of Moringa based feed additives on growth performance and carcass quality of broiler chicken. Trop Agric Res. 24 (1): 12-20.

Etches R. J., T. M. John, \& A. M. Verrinder Gibbins. 2008. Behavioural, physiological, neuroendocrine, and molecular responses to heat stress. In: Daghir NJ, editor. Poult. Prod. Hot Clim. p. 46-49.

Frandson R.D. 2000. Anatomi dan Fisiologi Ternak 4th ed (Gadjah Mada University Press: Yogyakarta (ID).

Gladine C., C. Morand, E. Rock, D. Gruffat, D. Bauchart, \& D. Durand. 2007. The antioxidative effect of plant extract rich polyphenols differs between liver and muscle tissues in rat fed n-3 PUFA rich diet. Anim. Feed Sci. Techno. 139: 257-272.

Guyton C. A. 1992. Fisiologi Kedokteran. Penerbit Buku Kedokteran EGC.

Hartati S. C. D. 2012. Korelasi antara kadar glikogen, asam laktat, $\mathrm{pH}$, daging, dan susut masak daging domba setelah pengangkutan. Jurnal Agri Science. 3(5): 4-5.

Iwai K., N. Nakaya, Y. Kawasaki, \& H. Matsue. 2002. Antioxidative Functions of Natto, A Kind of Fermented Soybeans: Effect on LDL Oxidation and Lipid Metabolism in Cholesterol-Fed Rats. J. Agric. Food Chem. 50: 3597-3601.

Jiang S. Q., Z. Y. Jiang, Y. C. Lin, P. B. Xi, \& X. Y. Ma. 2007. Effect of soy isoflavone on performance, meat quality, and antioxidative property of male broilers fed oxidative fish oil. Asian-Aust. J. Anim. Sci. 20: 12521257.

Joseph L. P., W. A. Dozier, H. A. Olanrewaju, J. D. Davis, H. Xin, \& R. S. Gates. 2012. Effect of TemperatureHumidity Index on Live Performance in Broiler
Chickens Grown From 49 to 63 Days of Age. Ninth International Livestock Environment Symposium. Valencia. Spain.

Kermanshahi H. \& M. Ernadi. 2007. Effect of Turmenic Rhizome Powder on The Activity of Some Blood Enzyme in Broiler Chicken. Int. J. Poulty. Sci. 6 (1): 48-51.

Kusnadi E. 2009. Perubahan Malonaldehida Hati, Bobot Relatif Bursa Fabricus, dan Rasio Heterofil/Limfosit (H/L) Ayam Broiler yang diberi Cekaman Panas. Media Peternakan. 32(2); 81-87.

Mitchell M.A. \& P. J. Kettlewell. 1994. Road transportation of broiler chickens: introduction of physiological stress. World's Poultry Science Journal. 50 (01): 57-59.

Mitchell M. A. \& P. J. Kettlewell. 2009. Welfare of Poultry during Transport - a Review Proceedings of The 8th European Symposium on Poultry Welfare. Cervia. Italy. 18-22 May. 90-100.

Ondrasovicova O., L. Saba, S. Smirjakova, M. Vargova, M. Ondrasovic, S. Mata, K. Lakticova \& W. Wnuk. 2008. Effects of vehicle-road transport on blood profile in broiler chickens. Departement of The Environment. University of Veterinary Medicine. Komenskeho 73. $041-81$.

Purwadi B. A., A. S.Teysar, M. Retno. 2008. Pengaruh jarak transportasi terhadap biokimia darah ayam broiler. Jurnal Ilmu-ilmu Peternakan. 28 (2): 129 - 133.

Sastradipradja D., S.H.S. Sikar, R. Wijayakusuma, T. Ungerer, A. Maad, H. Nasution, R. Suriawinata, \& R. Hamzah. 1989. Fisiologis Veteriner. Pusat Antar Universitas Ilmu Hayati. Bogor (ID): Institut Pertanian Bogor.

Scanes C. G., G Brant, \& M. A. Ensminger. 2004. Poultry Science. 4th. Ed. New Jerset. USA: Pearson/Prentice Hall.

Siegel H. S. 1995. Stress, strains, and resistance. Br Poult Sci. 36: $3-22$.

Singh R. P., K. N. C. Murthy, \& G. K. Jaya. 2002. Studies on the Antioxidant Activity of Pomegranate (Punica granatum) Peel and Seed Extracts Using in Vitro Models. J. Agric. Food Chem. 50: 81-86.

Tao X. \& H Xin. 2003. Temperature-Humidity-Velocity Index for Market-size Broilers. An ASAE Meeting Presentation.

Teeter R. G., M. O. Smith, \& C. J. Wiernusz. 1992. Broiler acclamation to heat distress and feed intake effects on body temperature in birds exposed to thermo neutral and high ambient temperature. Poultry Science. 71: 1101-1104.

Thaxton J. P. \& S. Puvodolpirod. 2000. Model of physiological stress in chicken. Poult. Sci. 79: 391-395.

Valco M., L. Dieter, M. Jan, T. D. C. Mark, M. Milan, T. Joshua. 2010. Free radicals and antioxidants in normal physiological functions and human disease. The International Journal of Biochemistry \& Cell Biology. 39 (2007) 44-84.

Valko M., D. Leibfritz, J. Moncol, M. T. D. Cronin, M. Mazur, \& J. Tesler. 2007. Free radicals and antioxidants in normal physiological functions and human disease. 
The International Journal of Biochemistry \& Cell Biology. 39 (1): 44-84.

Whiting T. L., M. E. Drain, \& D. P. Rasali. 2007. Warm Weather Transport of Broiler Chickens in Manitoba. II. Truck Management Factors Associated with Death Loss in Transit to Slaughter. Can. Vet. J. 48. 148-154.
Yalcinkaya L., Gungor T, Basalan M, \& Erdem E. 2008. Mannan oligosaccharides (MOS) from Saccharomyces cerevisiae in broilers: Effects on performance and blood biochemistry. J. Vet. Anim. Sci. 32 (1): 43-48. 